\title{
THE IMPACT OF RENEWABLE AND NON-RENEWABLE ENERGY CONSUMPTION ON FINANCIAL DEVELOPMENT: EVIDENCE FROM EMERGING COUNTRIES
}

\author{
Yenilenebilir ve Yenilenemez Enerjinin Finansal Gelişim Üzerindeki Etkisi: \\ Gelişmekte Olan Ülkelerden Kanıtlar
}

\section{Feyyaz ZEREN* \& Süleyman Serdar KARACA*}

\section{Keywords: \\ Financial \\ Development, Renewable Energy Consumption, Non- Renewable Energy Consumption, Panel Cointegration Test, Panel Causality Test}

JEL Codes: C33, P43, Q20

\section{Anahtar Kelimeler: Finansal Gelişim, Yenilenebilir Enerji Tüketimi, Yenilenemeyen Enerji Tüketimi, Finansal Gelișim, Panel Eşbütünleşme, Panel Nedensellik}

JEL Kodları: C33, P43, Q20

\begin{abstract}
Energy is an essential factor for countries to accomplish sustainable development and the importance of renewable energy has enhancing day by day. Over the last three decades the relationship between renewable energy consumption (RNW) and economic growth as well as energy consumption (EC) and financial development (FD) has intensely studied. In this paper the relationship between RNW, non-renewable energy consumption (non-RNW) and FD is investigated for top emerging countries of Bloomberg. The financial system deposits to GDP, deposit money bank assets to GDP and private credit to GDP have considered as FD indicators in the paper that investigates the period of 1980-2018. The long-term relationship between the variables was studied with Westerlund (2007) panel cointegration test and the direction of this relationship was examined with Pesaran (2006) CCE-MG panel cointegration estimator. The existence of causality among the variables was analyzed with Dumitrescu and Hurlin (2012) panel causality test. According to the cointegration test results, a positive long-run relationship was found between RNW and FD. Also, there is a bidirectional causality finding between RNW and FD, and there is a one-way causality finding from FD to non-RNW.
\end{abstract}

\section{Özet}

Enerji, ülkelerin sürdürülebilir kalkınmayı başarması için önemli bir faktördür ve yenilenebilir enerjinin önemi her geçe gün artmaktadır. Son otuz yılda yenilenebilir enerji tüketimi - ekonomik büyüme ve enerji tüketimi - finansal gelişim ilişkileri yoğun bir şekilde araştırılmıştır. Bu çalışmada Bloomberg'in en çok gelişmekte olan ülkeleri için yenilenebilir enerji tüketimi, yenilenemeyen enerji tüketimi ve finansal gelişim arasındaki ilişkiler araştırılmıştır. 1980-2018 dönemini ele alan çalışmada bankalardaki mevduatların GSYİH'ye oranı, finansal sistem mevduatının GSYİH'ye ve özel kredilerin GSYİH'ye oranı finansal gelişim göstergeleri olarak kullanılmıştır. Değişkenler arasındaki uzun vadeli ilişki Westerlund (2007) panel eşbütünleşme testi ile incelenmiş ve bu ilişkinin yönü Pesaran'ın (2006) CCEMG panel eşbütünleşme tahmincisi ile belirlenmiştir. Dumitrescu ve Hurlin (2012) tarafından geliştirilen panel nedensellik testi vasıtasıyla ile değişkenler arasında nedenselliğin yönü araştırılmıştır. Elde edilen panel eşbütünleşme testi sonuçlarına göre, yenilenebilir enerji tüketimi ve finansal gelişim arasında uzun dönemli pozitif yönlü bir ilişki bulunmuştur. Öte yandan, yenilenebilir enerji tüketimi ile finansal gelişim arasında çift yönlü nedensellik bulgusuna rastlanmış olup, finansal gelişimden yenilenemez enerji tüketimine doğru ise tek yönlü nedensellik bulgusu söz konusudur.

\footnotetext{
* Corresponding Author, Assoc. Prof. Dr., Yalova University, Faculty of Economics and Administrative Sciences, Department of International Trade and Finance, feyyaz.zeren@yalova.edu.tr, ORCID: 00000003-0163-5916

** Prof. Dr., Malatya Turgut Özal University, Faculty of Business and Management Sciences, Department of Accounting and Finance, suleymanserdar.karaca@ozal.edu.tr, ORCID: 0000-0002-5424-5359
}

Makale Geliş Tarihi (Received Date): 27.04.2020 ～Makale Kabul Tarihi (Accepted Date): 16.11.2020 
F. Zeren \& S. S. Karaca, “The Impact of Renewable and Non-Renewable Energy Consumption on Financial Development: Evidence From Emerging Countries"

\section{Introduction}

Renewable energy has become an important factor for countries to achieve sustainable development. Both renewable energy sources and non-renewable sources are important energy sources that affect financial development and economic growth. The KYOTO Protocol United Nations Framework Convention on Climate Change, which came into force in 1994, encourages the countries to reduce greenhouse gas emissions, collaborate on research, technology and protect greenhouse gas sinks (e.g. forests, oceans, lakes). In this context, countries have sought renewable energy sources to reduce their greenhouse gas emissions. Accordingly, the exchange of RNWs between 1948-2015 is presented in Figure 1.

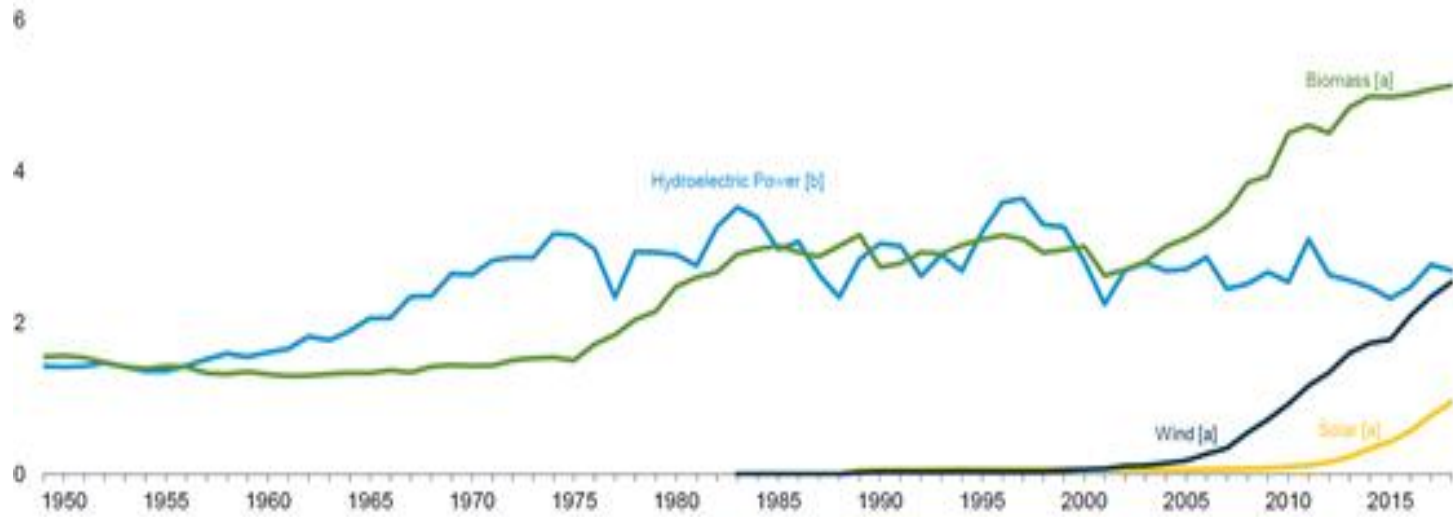

Figure 1. Renewable Energy Consumption (Quadrillion Btu)

Source: https://www.eia.gov/totalenergy/data/29/10/2019

When the graphic above is analysed, it is clear that Biomass EC has especially increased significantly in recent years. In addition, the view of energy sources from the 2050 perspective by the USA Energy Information Administration (EIA) is as in Figure 2.

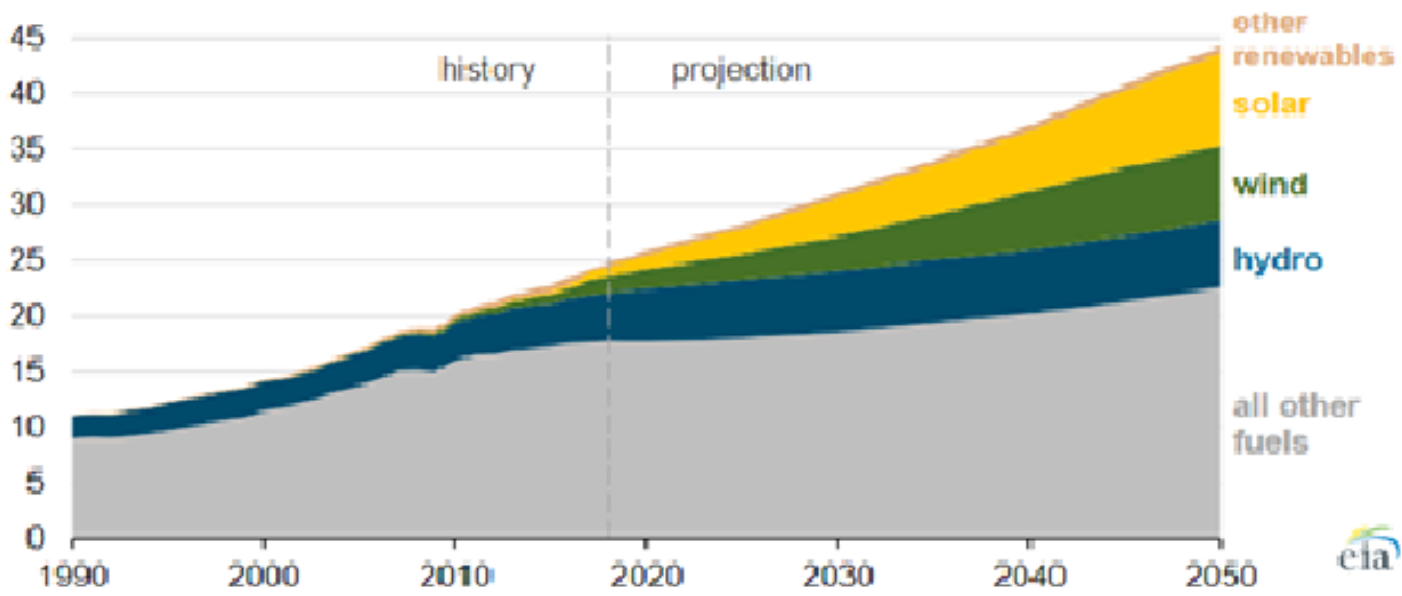

Figure 2. World Net Electricity Generation (Trillion kilowatt hours), (1990-2050)

Source: https://www.eia.gov/todayinenergy/detail.php?id=41533/29/10/2019 
While renewable energy sources are about $30 \%$ of world electricity in 2018, this figure is expected to increase to $50 \%$ until 2050.

In the studies conducted in the last 10 years, it is especially seen that FD has started to take a role in explaining the factors that determine EC. The first examples of studies investigating the relationship between EC and FD coincide in 2009. The first studies to investigate the relationship belongs to Brunnschweiler (2009) and Dan and Lijun (2009). However, the first study to seriously discuss and explain the relationship between EC and FD was conducted by Sadorsky in 2011 and this study pioneered the literature.

Sadorsky (2011) stated that the relationship between these two variables may result from several possible reasons. The prices and consumption prices of vehicles that provide EC such as cars, houses, dishwashers and refrigerators can affect the money needs of people. In this context, how EC is priced can indirectly be reflected in FD indicators. In the opposite direction, FD can lead to more economical use of energy resources and, accordingly, to lower EC costs. Besides, the increase in economic prosperity due to the increasing FD may lead to the incentive to spend money comfortably and consequently an increase in EC.

In this study, it is aimed to reveal the possible effects of renewable and non-renewable energy consumption on financial development. The differences between renewable and nonrenewable energy consumption are thought to have different effects on financial development. In this regard, the summary of the studies in the literature, the econometric method used, the findings obtained, and suggestions for future studies are tried to be presented.

\section{Previous Literature Review}

Many studied have made to investigate the relationship between EC and FD by methods such as Generalized Method of Moments (GMM), time series causality tests and some panel causality test in the literature. The focus of the study is to explain the renewable and nonrenewable forms of energy and their impact on FD. However, in the literature, the number of studies investigating this situation is very limited. Studies investigating the relationship between EC and FD are briefly described below.

Sadorsky (2010) analyzed the relationship between EC and FD for 22 developing countries and determined a significant positive relationship between these two variables using the GMM model. In another study, Sadorsky (2011) found similar findings for 9 countries from Central and Eastern European Border Economies using the GMM model. Kakar, Khilji and Khan (2011) examined Pakistan and found that FD is a remarkable measurement tool for the effectuality of energy use. Xu (2012) determined a positive relationship between these two variables for China using the GMM model. In another study using GMM, Çoban and Topcu (2013) examined the European Union (EU) countries and found a significant nexus between these two variables for the former EU countries but did not find any relationship for other countries. Shahbaz and Lean (2012) found that EC was associated with FD and industrialization in their studies, which examined the Tunisian economy using the Granger causality test. AlMulali and Sab (2012a) examined Sub-Saharan African countries using the Pedroni panel cointegration and panel causality test. As a result, they found that EC plays a crucial role in financial and economic development. In another study of Al-Mulali and Sab (2012b), they analyzed 19 countries consisting of developed and developing countries and reached similar 
findings. Al-Mulali and Lee (2013) examined the Gulf Cooperation Council and this time they found the opposite findings. According to the study, they found that FD positively increased EC.

Unlike other studies, Chtioui (2012) concluded that EC is the Granger cause of FD in his study dealing with Tunisia. Mehrara and Musai (2012), on the other hand, concluded that these two variables have an integrated structure in the long term for Iran with ARDL cointegration test. Islam, Shahbaz, Ahmed and Alam (2013) conducted a traditional Granger Causality test using the Vector Error Correction Model (VECM) in their paper in Malaysia and concluded that EC is affected by both financial and economic development. Zeren and Koç (2014) found that the relationship between EC and FD differs in the case of positive and negative shocks in their study of 7 New Industrialized countries. As a result of the study, they found that both positive and negative shocks exist for Malaysia and Mexico, while they found that there was a causality from EC to FD in negative shocks only for the Philippines. They also found bidirectional causality between India and Turkey. However, they could not achieve this result for South Africa. Salman and Atya (2014) studied three Northern African countries such as Algeria, Egypt and Tunisia. In their study, they dealt with the period of 1980-2010 with the granger causality test. As a result, there is a positive nexus between EC and FD for Algeria and Tunisia, whereas this relationship is negative for Egypt. Ali, Yusop and Hook (2015) discussed Nigeria for the period 1972Q1-2011Q4 using ARDL approach and quarterly data. As a result of the study, a negative relationship was found between EC and FD.

Chang (2015) used panel threeshold regression for 1999-2008 and 58 countries in his study. According to the results obtained, when private and domestic loans are used as FD indicators, EC increases FD, while traded stocks and stock market transaction volume are used as FD indicators, and EC decreases FD. Paramati, Ummalla and Apergis (2016) used panel cointegration and panel causality tests in their studies of 20 developing countries. They concluded that stock markets positively affected EC for the period 1991-2012. In another study examining South Asian countries consisting of India, Pakistan, Bangladesh and Sri Lanka, Akhtar, Sheikh and Altaf (2016) used data from 1974-2013 and consequently found bidirectional causality between EC and FD. Mahalik, Babu, Loganathan and Shahbaz (2017) found a cointegration relationship between EC and FD for Saudi Arabia in their studies, which examined the period between 1971-2011. These findings were obtained with the help of Pesaran's (2001) ARDL test and the combined cointegration test developed by Bayer-Hanck (2013).

Destek (2017) examined 17 developing countries for the period 1991-2015. In his study, he used the Common Correlated Effect (CCE) cointegration estimator, which takes into account cross-section dependency. According to the findings obtained as a result of the study, developments in financial markets have been shown to reduce EC. Topcu and Altay (2017) viewed for Turkey in the 1989-2011 period. Looking at the findings, even with disaggregated data, there is a statistically significant nexus between EC and FD.

Topcu and Payne (2017) examined the relationship between the FD index and EC for the period of 1990-2014 in their study where they examined 32 high-income countries. The findings are that there is no relationship between these two variables but increases in stock market returns reduce EC. Çağlar and Kubar (2017) examined the 1969-2014 period by the Fourier Toda Yamamoto causality test for Turkey. As a result of the study, while no findings were 
found between RNW and FD, it was determined that FD was the cause of fossil EC. Güngör, Korkmaz, Karaca and Keskin Benli (2017) 1985-2015 periods for Argentina, China, South Korea, Israel, Malaysia, Mexico and Turkey were examined. As a result of their work, they identified one-way causality from primary EC to FD.

In the literature, although many studies are examining the nexus between $\mathrm{EC}$ and FD, the number of studies examining the relationship between renewable energy and FD are very low. Çetin and Bakırtaş (2018), one of the first studies conducted in this context, discussed the longterm relationship between RNW and FD, covering the years 1991-2011 for G-7 countries. As a result of the research, there is a long-term relation between RNW and real GDP, total EC, oil prices and FD.

In another study examining this relationship, Eren, Taspinar and Gokmenoglu, (2019) studied the Indian sample and examined the impact of FD and economic growth on the renewable energy source. In this paper, they concluded that FD has a significant and positive effect on renewable energy sources. They also found that renewable energy is based on FD in the long run.

The studies described up to this stage are presented in Table 1 as a summary. When the studies are examined, it is seen that System GMM, Granger causality, Panel Cointegration and Panel Causality tests are mainly used. 
Table 1. Literature Review

\begin{tabular}{|c|c|c|c|c|}
\hline Author & Country/Countries & Data & Method & Empirical Findings \\
\hline Dan and Lijun (2009) & China & $1985-2006$ & Granger causality & $\mathrm{EC} \rightarrow \mathrm{FD}$ \\
\hline Sadorsky (2010) & 22 emerging countries & $1990-2006$ & System GMM & There is a positive relation between EC and FD \\
\hline Sadorsky (2011) & $\begin{array}{l}9 \text { Central and Eastern } \\
\text { European frontier economies }\end{array}$ & $1996-2006$ & System GMM & There is a positive relation between EC and FD \\
\hline Kakar et al. (2011) & Pakistan & 1980-2009 & Granger causality & $\mathrm{FD} \rightarrow \mathrm{EC}$ \\
\hline $\mathrm{Xu}(2012)$ & China & 1999-2009 & System GMM & $\begin{array}{l}\text { There is a positive and significant relation between EC and } \\
\text { FD }\end{array}$ \\
\hline Chtioui (2012) & Tunisia & $1972-2010$ & Granger causality & $\mathrm{EC} \rightarrow \mathrm{FD}$ \\
\hline Mehrara and Musai (2012) & Iran & 1970-2009 & ARDL bound test & $\mathrm{EC}=\mathrm{FD}$ \\
\hline Shahbaz and Lean (2012) & Tunisia & $1971-2008$ & Granger causality & $\mathrm{EC} \leftrightarrow \mathrm{FD}$ \\
\hline Al-Mulali and Sab (2012a) & $\begin{array}{l}\text { Sub Saharan African } \\
\text { countries }\end{array}$ & $1980-2008$ & $\begin{array}{l}\text { Pedroni panel cointegration } \\
\text { and panel causality }\end{array}$ & $\mathrm{EC}=\mathrm{FD} . \mathrm{EC}$ has a positive impact on FD. \\
\hline Al-Mulali and Sab (2012b) & 19 selected countries & $1980-2008$ & $\begin{array}{l}\text { Pedroni panel cointegration } \\
\text { and panel causality }\end{array}$ & $\mathrm{EC}=\mathrm{FD} . \mathrm{EC}$ has a positive impact on FD. \\
\hline Al-Mulali and Lee (2013) & $\begin{array}{l}\text { Gulf Cooperation Council } \\
\text { (GCC) countries }\end{array}$ & 1980-2009 & $\begin{array}{l}\text { Pedroni panel cointegration } \\
\text { and panel causality }\end{array}$ & $\begin{array}{l}\mathrm{EC} \leftrightarrow \mathrm{FD} . \mathrm{EC}=\mathrm{FD} \\
\text { FD increases EC positively. }\end{array}$ \\
\hline Çoban and Topcu (2013) & $\begin{array}{l}\text { New and Old European } \\
\text { Union (EU) Countries }\end{array}$ & $1990-2001$ & System GMM & $\begin{array}{l}\text { While there is a positive relation between EC and FD for the } \\
\text { old EU countries, there is no relationship for the new EU } \\
\text { countries. }\end{array}$ \\
\hline Islam et al. (2013) & Malaysia & 1971-2009 & Granger causality & $\mathrm{FD} \rightarrow \mathrm{EC}$ \\
\hline Zeren and Koç (2014) & $\begin{array}{l}\text { Newly industrialized } \\
\text { countries }\end{array}$ & $1971-2010$ & $\begin{array}{l}\text { Hatemi-J (2012) } \\
\text { asymmetric causality }\end{array}$ & $\begin{array}{l}\mathrm{EC} \leftrightarrow \text { FD for India, Turkey and Thailand. } \\
\mathrm{EC} \rightarrow \text { FD for Malaysia Mexico and Philippines. }\end{array}$ \\
\hline Salman and Atya (2014) & Egypt, Algeria and Tunisia & $1980-2010$ & $\begin{array}{l}\text { Granger causality test and } \\
\text { error correction model }\end{array}$ & $\begin{array}{l}\text { For Algeria and Tunisia, there is a positive relation between } \\
\text { EC and FD, while for Egypt this relation is negative. }\end{array}$ \\
\hline Ali et al. (2015) & Nigeria & $\begin{array}{l}\text { 1972Q1- } \\
\text { 2011Q4 }\end{array}$ & ARDL bound test & There is a negative relation between EC and FD. \\
\hline Chang (2015) & 58 countries & 1999-2008 & Panel threshold regression & $\begin{array}{l}\text { The direction of the effect of EC on FD depends on the } \\
\text { variable used as the indicator of FD used. }\end{array}$ \\
\hline
\end{tabular}


Table 1. Literature Review (Cont'd)

\begin{tabular}{|c|c|c|c|c|}
\hline Author & Country/Countries & Data & Method & Empirical Findings \\
\hline Akhtar et al. (2016) & $\begin{array}{l}\text { Pakistan, India, Sri-Lanka, } \\
\text { Bangladesh }\end{array}$ & $1974-2013$ & Dumitrescu Hurlin (2012) panel causality & $\mathrm{EC} \leftrightarrow \mathrm{FD}$ \\
\hline Paramati et al. (2016) & 20 emerging market countries & $1991-2012$ & Westerlund (2007) panel cointegration & $\mathrm{EC}=\mathrm{FD}$. Stock markets positively impact on EC \\
\hline Mahalik et al. (2017) & Saudi Arabia & $1971-2011$ & $\begin{array}{l}\text { Pesaran's (2001) ARDL and Bayer-Hanck } \\
\text { (2013) combined cointegration test }\end{array}$ & $\mathrm{EC}=\mathrm{FD}$ \\
\hline Destek (2017) & 17 developing countries & $1991-2015$ & CCE cointegration estimator & $\begin{array}{l}\text { Developments in financial markets have been } \\
\text { shown to reduce EC. }\end{array}$ \\
\hline Topcu and Altay (2017) & Turkey & $1989-2011$ & $\begin{array}{l}\text { Pedroni cointegration and } \\
\text { Dumitrescu-Hurlin (2012) panel causality }\end{array}$ & $\mathrm{EC}=\mathrm{FD}$ \\
\hline Topcu and Payne (2017) & 32 High income countries & $1990-2014$ & CCE cointegration estimator & $\begin{array}{l}\mathrm{FD} \neq \mathrm{EC} \text {. However, increase in stock market } \\
\text { returns reduce EC. }\end{array}$ \\
\hline Çağlar and Kubar (2017) & Turkey & $1969-2014$ & Fourier Toda Yamamoto causality test & $\begin{array}{l}\text { RNW = FD. } \\
\text { FD } \rightarrow \text { EC. }\end{array}$ \\
\hline Güngör et al. (2017) & $\begin{array}{l}\text { Argentina, China, South } \\
\text { Korea, Israel, Malaysia, } \\
\text { Mexico and Turkey }\end{array}$ & $1985-2015$ & $\begin{array}{l}\text { Westerlund (2007) panel cointegration, } \\
\text { Holtz-Eakin, Newey and Rosen panel } \\
\text { causality }\end{array}$ & $\begin{array}{l}\mathrm{EC}=\mathrm{FD} \\
\mathrm{EC} \rightarrow \mathrm{FD}\end{array}$ \\
\hline $\begin{array}{l}\text { Çetin and Bakırtaş } \\
\text { (2018) }\end{array}$ & G7 Countries & $1991-2011$ & PMG panel cointegration estimator & $\mathrm{RNW}=\mathrm{FD}$. \\
\hline Eren et al. (2019) & India & $1971-2015$ & $\begin{array}{l}\text { Maki (2012) cointegration and Granger } \\
\text { causality test }\end{array}$ & $\begin{array}{l}\mathrm{FD}=\mathrm{RNW} \\
\mathrm{FD} \rightarrow \mathrm{RNW}\end{array}$ \\
\hline
\end{tabular}
there is no causality. 


\section{Econometric Methodology}

Panel data analysis has some advantages instead of time series in econometric studies. Having a cross-section and a time dimension of the data is the major advantage of using panel data analysis. It is possible to indicate a few causality tests used in the literature on panel causality. These are GMM tests used when the dimension of the cross-section is larger than the time dimension, and Dumitrescu-Hurlin (2012) and Emirmahmutoglu-Kose's (2011) Panel Fisher tests used when the time dimension is larger than the cross-section dimension. In the paper, it was decided that it would be appropriate to use one of the Dumitrescu and Hurlin (2012) or Panel Fisher (2011) tests since the time dimension was larger than the cross-section dimension. Dumitrescu and Hurlin (2012) test is used in the panel if all series are stationary at the same level, and Panel Fisher (2011) test is used if the series is stationary at different levels.

Dumitrescu and Hurlin (2012) panel causality test that regard the cross-sectional dependency was used in this study. The basic hypothesis in that test indicates the absence of a homogeneous causality nexus in the panel, while the alternative hypothesis indicates the presence of a heterogeneous causality relationship in at least one cross-section. The main hypothesis in this study is to research the existence of a homogeneous causality nexus, while the alternative hypothesis is to analyze causality the existence of a heterogeneous structure.

The test statistic used to test the basic hypothesis in this analysis is the simple average of individual Wald statistics (Bozoklu and Y1lanc1, 2013). So;

$$
W_{N, T}^{H n c}=\frac{1}{N} \sum_{i=1}^{N} W_{i, t}
$$

Where Wit shows Wald Test Statistic to test causality for the country. Individual Wald statistics are used for small values of $\mathrm{T}$. Since T Statistics do not converge to the chi-square distribution, Dumitrescu and Hurlin (2012) suggested using the estimated standardized statistics for the mean and variance of this unknown distribution using the forecast values. This statistic is calculated as below.

$$
Z_{N, T}^{H N C}=\frac{\sqrt{N}\left[W_{N, T}^{H n c}-\sum_{i=1}^{N} E\left(W_{i, t}\right]\right.}{\sqrt{\sum_{i=1}^{N} \operatorname{Var}\left(W_{i, t}\right)}}
$$

In equation 2, i represents number of countries, $\mathrm{W}$ is Wald Statistics and $\mathrm{T}$ is the number of periods. More econometric information on this method can be found in studies by Dumitrescu and Hurlin (2012).

\section{Data and Empirical Findings ${ }^{1}$}

The data were handled annually and countries were picked out from top emerging countries of Bloomberg as a recognized institution in the entire financial community. These countries consist of Brazil, Chile, Philippines, Hungary, India, Indonesia, Mexico, Morocco, Peru, Poland, South Africa, South Korea, Malaysia, Turkey and Thailand. The data set of the

\footnotetext{
${ }^{1}$ Ethics of research and publication were followed in this study, which does not require permission from the ethics committee and / or legal / special permission.
} 
study covers the period of 1980-2018. The data of RNW and non-RNW is measured as in Million Kwh This data was taken from the official website of United State EIA. FD indicators were analyzed on three different variables. These are deposit money bank assets to GDP, private credit to GDP and financial system deposits to GDP (Çoban and Topcu, 2013; Sadorsky, 2010; Sadorsky, 2011). FD data was obtained from the official websites of Organization for Economic Co-operation and Development (OECD) and the World Bank. The models created in this context are as follows;

$$
\begin{aligned}
& \ln \mathrm{RNW}=\alpha+\ln \mathrm{FD} 1+\ln \mathrm{FD} 2+\ln \mathrm{FD} 3+\mathrm{u} \\
& \ln \mathrm{Non}-\mathrm{RNW}=\mathrm{a}+\ln \mathrm{FD} 1+\ln \mathrm{FD} 2+\ln \mathrm{FD} 3+\mathrm{c}
\end{aligned}
$$

Findings obtained from cross-section dependency test are great importance in panel data analysis. Because the findings to be obtained from this pretest are the deciding factor in the selection of the unit root, cointegration and causality test to be used.

Much of the studies used conventional CDLM test of Breusch and Pagan (1980) up to 2008 to investigate the presence of cross-section dependence. However, this method is a test that gives reliable results if the group averages are zero, but the results are unreliable if the individual averages are different from zero. With the work of Pesaran and Yamagata (2008), this deficiency was eliminated by participating in the test statistics of variance and average. Therefore, the $\mathrm{CDLM}_{\text {adj }}$ test, which gives the new cross-section dependency test statistics, was used in the study. According to the findings in Table 2, Breusch and Pagan's (1980) CDLM test indicated that four of the panels had cross-sectional dependence, while Pesaran and Yamagata (2008) showed the presence of cross-sectional dependence on all panels used in the study.

Table 2. The Results of Cross Section Dependence Test

\begin{tabular}{lcccc}
\hline & CDLM & p-value & CDLM $_{\text {adj }}$ & p-value \\
\hline RNW & 137,47 & 0.131 & 15.07 & 0.00 \\
Non-RNW & 163.06 & 0.005 & 27.65 & 0.00 \\
FD1 & 541.88 & 0.00 & 7.49 & 0.00 \\
FD2 & 599.30 & 0.00 & 3.98 & 0.00 \\
FD3 & 819.37 & 0.00 & 9.51 & 0.00 \\
\hline
\end{tabular}

According to Table 2, unit root, cointegration and causality tests that allow the crosssection dependency should be used. In such a situation, the panel unit root analysis is to do firstly. The cross-sectionally Augmented Dickey - Fuller (CIPS) test results point out that while all panels have a unit root at the level, they become stationary at the first difference.

Table 3. The Results of CIPS Unit Root Test

\begin{tabular}{lcc}
\hline & CIPS & CIPS in 1 st $_{\text {dif. }}$ \\
\hline RNW & -2.92 & $-4.85^{* *}$ \\
Non-RNW & -2.07 & $-4.36^{* *}$ \\
FD1 & -2.43 & $-3.86^{*}$ \\
FD2 & -2.28 & $-3.87^{*}$ \\
FD3 & -2.51 & $-3.70^{*}$ \\
\hline Note: $*$ 90\% and ** 95\% indicate significance level of reliability.
\end{tabular}


Table 3 indicates that panels are stationary in their first differences. So, the cointegration relationship between the panels will be analyzed. In this paper, Westerlund (2007) panel cointegration test which shows the results in cases with and without cross-section dependence will be used. While asymptotic probability value uses in the presence of cointegration relation in cases of the absence of cross-section dependence and bootstrap critical value uses in cases of cross-section dependency. Asymptotic probability value is used to conclude the presence of cointegration relations. Bootstrap critical values will be examined since both panels in the study have cross-section dependency.

Table 4. The Results of Westerlund Panel Cointegration Test

\begin{tabular}{lccc}
\hline & LM Statistics & Asymptotic p-value & Bootstrap p-value \\
\hline RNW vs FD1 & 54.15 & 0.00 & 0.49 \\
RNW vs FD2 & 52.06 & 0.00 & 0.58 \\
RNW vs FD3 & 16.95 & 0.00 & 0.88 \\
Non-RNW vs FD1 & 23.86 & 0.00 & 0.84 \\
Non-RNW vs FD2 & 61.35 & 0.00 & 0.46 \\
Non-RNW vs FD3 & 49.39 & 0.00 & 0.67 \\
\hline
\end{tabular}

According to the findings obtained, the zero hypothesis that there is cointegration between EC and FD for all matches is accepted. That's why, there is a long-term relationship between both RNW-FD and nonRNW-FD. Dumitrescu and Hurlin (2012) panel causality test results, which are the proper choice in each case where the panels are stationary at I (1) level and have a cross-section dependency, are shown in Table 5.

It is seen that there is a causality from both RNW and non-RNW to FD at the level of 0.01 significance. The findings are valid for all three indicators of FD. On the other hand, while it was seen that there was causality from FD to RNW, one of these findings was accepted with 0.01 significance, the other 0.05 , and the last one with 0.10 . However, causality is not observed from FD to non-RNW.

Table 5. The Results of Dumitrescu and Hurlin Panel Causality Test

\begin{tabular}{|c|c|c|c|}
\hline & W-Stat. & Zbar-Stat. & p-value \\
\hline RNW >> FD1 & 3.93 & 3.08 & 0.00 \\
\hline RNW >> FD2 & 3.91 & 3.04 & 0.00 \\
\hline RNW >> FD3 & 5.42 & 5.65 & 0.00 \\
\hline Non-RNW >> FD1 & 6.72 & 7.89 & 0.00 \\
\hline Non-RNW >> FD2 & 5.45 & 5.68 & 0.00 \\
\hline Non-RNW >> FD3 & 7.14 & 8.61 & 0.00 \\
\hline FD1 >> RNW & 3.30 & 2.00 & 0.04 \\
\hline FD2 $\gg$ RNW & 3.18 & 1.78 & 0.07 \\
\hline FD3 >> RNW & 4.92 & 4.72 & 0.00 \\
\hline FD1 > Non-RNW & 3.09 & 1.63 & 0.10 \\
\hline FD2 $>>$ Non-RNW & 3.09 & 1.62 & 0.10 \\
\hline FD3 >> Non-RNW & 3.11 & 1.65 & 0.10 \\
\hline
\end{tabular}

The most appropriate analysis to be performed after the cointegration and causality test obtained is to decide the direction of cointegration. For this reason, CCE was used in this stage 
of the study, which provides estimation of long-term regression coefficients. The findings are presented in Table 6.

Table 6. The Results of CCE-MG Estimation

\begin{tabular}{lcccc}
\hline $\begin{array}{c}\text { Independent } \\
\text { Variable }\end{array}$ & $\begin{array}{c}\text { Dependent } \\
\text { Variable }\end{array}$ & Coefficient & $\begin{array}{c}\text { Standard } \\
\text { Deviation }\end{array}$ & T Statistics \\
\hline RNW & FD1 & 0.049 & 0.10 & 0.47 \\
RNW & FD2 & 0.192 & 0.17 & 1.10 \\
RNW & FD3 & 0.094 & 0.10 & 0.94 \\
Non-RNW & FD1 & 0.155 & 0.19 & 0.83 \\
Non-RNW & FD2 & 0.207 & 0.27 & 0.77 \\
Non-RNW & FD3 & -0.188 & 0.21 & -0.87 \\
\hline
\end{tabular}

According to the results obtained with the Pesaran's CCE-MG method (2006), the relationship between RNW and FD is positive. The relationship between non-RNW and FD appears contradictory results. While the relationship between Deposit Money Bank Assets to GDP and Private Credit by Deposit Money Banks to GDP variables and EC is positively determined, there is a negative relation between Financial System Deposits to GDP and EC. Accordingly, the certainty in the positive relationship between RNW and FD triggers use of RNW.

\section{Conclusion and Discussion}

In today's world, energy needs increased with economic and financial development. In this process, renewable energy sources, which can reduce the energy costs of the countries, have become important. In this context, the relationship between renewable energy sources and economic growth and financial development has reached very important dimension for developing countries.

In this study, it is aimed to reveal the possible effects of renewable and non-renewable energy consumption on financial development. The differences between renewable and nonrenewable energy consumption are thought to have different effects on financial development.

The relationship between RNW and non-RNW and FD and the direction of this relationship are examined in this study. The long-term relationship between the variables was determined by Westerlund (2007) panel cointegration test and the direction of this relationship was determined by Pesaran (2006) CCE-MG coefficient estimator. The causality relationship between the variables examined was examined by Dumitrescu-Hurlin (2012) panel causality test.

As a result, a positive correlation was observed between RNW and FD. While causality was determined from RNW to FD, it could not be determined from FD to non-RNW. Here contradictory results have occurred. While a positive correlation was determined with the ratio of assets of deposit banks to GDP and the ratio of private loans of deposit banks to GDP, a negative relation was found with the ratio of financial system deposits to GDP. On the other hand, a causality was determined from FD to RNW. However, no causality has been found from FD to non-RNW. As a reason, it can be interpreted as increases in FD lead to the use of relatively expensive renewable energy sources. The usage of environmentally friendly 
renewable energy sources will bring sustainable economic development along with it in the long term. Besides, since FD will result in more economical use of energy resources, this leads to lower EC costs. According to the findings, it is understood that the feedback hypothesis is valid for the relationship between RNW and FD, and the conservation hypothesis is valid for the relationship between non-RNW and FD.

Findings obtained from the study coincides with Dan and Luin (2009), Sadorsky (2011), Xu (2012), Mehrara and Musai (2012), Al-Mualali and Sab (2012b), Mahalk et al. (2017) Çetin and Bakırtaş (2018) and Eren et al. (2019) presents different results from Ali et al. (2015), Çağlar and Kubar (2017) studies.

This study has a unique structure in terms of being one of the first studies examining the relationship between EC as RNW and non-RNW and FD and in this respect, it provides valuable information to the reader. With the Kyoto protocol framework convention, countries have sought new energy sources to reduce their greenhouse gas emissions. To this end, different energy sources have been sought. Today, there has been a trend towards increasingly renewable energy sources. In this context, the impact of RNW on both economic growth and FD is supported by studies conducted. Therefore, with the result of this study, countries must develop their renewable energy resources in terms of both FD and economic growth.

For future studies, the relationship between the types of renewable energy sources and economic growth and financial development can be examined. In this context, the types of renewable energy sources which are biomass, hydroelectric power, wind and solar energy, can be analyzed and the relationship between different energy sources and economic growth and financial development can be examined.

\section{Researchers' Contribution Rate Statement}

The authors declare that they have contributed equally to the article.

\section{Conflict of Interest Statement}

There is no potential conflict of interest in this study. 


\section{References}

Akhtar, M. H., Sheikh, M., R. and Altaf, A. (2016). Financial development, energy consumption and trade openness nexus: Empirical evidence from selected South Asian Countries. Pakistan Journal of Social Sciences, 36(1), 505-518. Retrieved from https://www.prdb.pk/

Ali, H. S., Yusop, Z. B. and Hook, L. S. (2015). Financial development and energy consumption nexus in Nigeria: An application of autoregressive distributed lag bound testing approach. International Journal of Energy Economics and Policy, 5(3), 816-821. Retrieved from https://www.econjournals.com/index.php/ijeep

Al-Mulali, U. and Lee, J. Y. M. (2013). Estimating the impact of the financial development on energy consumption: Evidence from the GCC (gulf cooperation council) countries. Energy, 60, 215-221. https://doi.org/10.1016/j.energy.2013.07.067

Al-Mulali, U. and Sab, C. N. B. C. (2012a). The impact of energy consumption and CO2 emission on the economic growth and financial development in the SubSaharan African Countries. Energy, 39, 180-186. https://doi.org/10.1016/j.energy.2012.01.032

Al-Mulali, U. and Sab, C. N. B. C. (2012b). The impact of energy consumption and CO2 emission on the economic and financial development in 19 selected countries. Renewable and Sustainable Energy Reviews, 16, 4365-4369. https://doi.org/10.1016/j.rser.2012.05.017

Bayer, C. and Hanck, C. (2013). Combining non-cointegration tests. Journal of Time Series Analysis, 34(1), 83-95. https://doi.org/10.1111/j.1467-9892.2012.00814.x

Bloomberg Official Websites. (2020). Top emerging countries [Dataset]. Retrieved from https://www.bloomberg.com

Bozoklu, Ş. ve Yılancı, V. (2013). Finansal gelişme ve iktisadi büyüme arasındaki nedensellik ilişkisi: Gelişmekte olan ekonomiler için analiz. [The causality relation between financial development and economic growth: An analysis for emerging economies]. Dokuz Eylül Üniversitesi İktisadi ve İdari Bilimler Fakültesi Dergisi, 28(2), 161-187. Retrieved from https://dergipark.org.tr/tr/pub/ije

Breusch, T. S. and Pagan A. R. (1980). The lagrange multiplier test and its applications to model specification in econometrics. Review of Economic Studies, 47(1), 239-253. Retrieved from https://www.restud.com/

Brunnschweiler, C. N. (2009). Oil and growth in transition countries. (CER-ETH-Center of Economic Research at ETH Zurich, Working Paper, 09/108). Retrieved from https://papers.ssrn.com/sol3/papers.cfm?abstract_id=1403313

Çağlar, A. E. ve Kubar, Y. (2017). Finansal gelişme enerji tüketimini destekler mi?. Süleyman Demirel Üniversitesi Sosyal Bilimler Enstitüsü Dergisi, 27, 96-121. Retrieved from https://dergipark.org.tr/tr/pub/sbe

Çetin, M. A. ve Bakırtaş, İ. (2018). Finansal gelişmişliğin yenilenebilir enerji tüketimi üzerindeki uzun dönemli etkileri: G-7 ülkeleri örneği. [The long run impacts of financial development on renewable energy consumption: A case of G-7 countries]. Trakya Üniversitesi Sosyal Bilimler Dergisi, 20(2), 37-54. https://doi.org/10.26468/trakyasobed.421105

Chang, S. C. (2015). Effects of financial developments and income on energy consumption. International Review of Economics and Finance, 35, 28-44. https://doi.org/10.1016/j.iref.2014.08.011

Chtioui, S. (2012). Does economic growth and financial development spur energy consumption in Tunisia?. Journal of Economics and International Finance, 4(7), 150-158. https://doi.org/10.5897/IJPS12.014

Çoban, S. and Topcu, M. (2013). The nexus between financial development and energy consumption in the EU: A dynamic panel data analysis. Energy Economics, 39, 81-88. https://doi.org/10.1016/j.eneco.2013.04.001.

Dan, Y. and Lijun, Z. (2009). Financial development and energy consumption: An empirical research based on Guangdong province. Papers presented at 2009 International Conference on Information 
F. Zeren \& S. S. Karaca, "The Impact of Renewable and Non-Renewable Energy Consumption on Financial Development: Evidence From Emerging Countries"

Management, Innovation Management and Industrial Engineering, Xi'an, China. doi:10.1109/ICIII.2009.334

Destek, M. A. (2017). Financial development and energy consumption nexus in emerging economies. Energy Sources, Part B: Economics, Planning, and Policy, 13(1), 76-81. https://doi.org/10.1080/15567249.2017.1405106

Dumitrescu, E. and Hurlin, C. (2012). Testing for granger non-causality in heterogeneous panels. Economic Modelling, 29(4), 1450-1460. https://doi.org/10.1016/j.econmod.2012.02.014

Emirmahmutoglu, F. and Kose, N. (2011). Testing for Granger causality in heterogeneous mixed panels. Economic Modelling, 28, 870-876. https://doi.org/10.1016/j.econmod.2010.10.018

Energy Information Administration of United Stated (2019). Energy [Dataset]. Retrieved from https://www.eia.gov/

Eren. B.M., Taspinar, N. and Gokmenoglu, K.K. (2019). The impact of financial development and economic growth on renewable energy consumption: Empirical analysis of India. Science of the Total Environment, 663, 189-197. https://doi.org/10.1016/j.scitotenv.2019.01.323

Fisher, A. (2011). Critical thinking: An introduction. Cambridge: Cambridge University Press.

Güngör, S., Korkmaz, Ö., Karaca, S. S. ve Keskin Benli, Y. (2017). Küresel gelişmeler bağlamında enerjide dışa bağımlı gelişmekte olan ülkelerde birincil enerji tüketimiyle finansal gelişme arasındaki ilişki. [The relationship between primary energy consumption and financial development in developing countries that were dependent on energy in context of global development]. Maliye Finans Yazlarl, (108), 123-142. https://doi.org/10.33203/mfy.311742

Islam, F., Shahbaz, M., Ahmed, A. U. and Alam, M. (2013). Financial development and energy consumption nexus in Malaysia: A multivariate time series analysis. Economic Modelling, 30, 435-441. https://doi.org/10.1016/j.econmod.2012.09.033

Kakar, Z.H., Khilji, B.A. and Khan, M. J. (2011). Financial development and energy consumption: Empirical evidence from Pakistan. International Journal of Trade, Economics and Finance, 2(6), 469-471. http://dx.doi.org/10.7763/IJTEF.2011.V2.150

Mahalik, M. K., Babu, M. S., Loganathan, N. and Shahbaz, M. (2017). Does financial development intensify energy consumption in Saudi Arabia?. Renewable and Sustainable Energy Reviews, 75, 1022-1034. http://dx.doi.org/10.1016/j.rser.2016.11.081

Mehrara, M. and Musai, M. (2012). Energy consumption, financial development and economic growth: An ARDL approach for the case of Iran. International Journal of Business and Behavioral Sciences, 2(6), 92-99.

Paramati, S. R., Ummalla, M. and Apergis, N. (2016). The effect of foreign direct investment and stock market growth on clean energy use across a panel of emerging markets economies. Energy Economics, 56, 29-41. https://doi.org/10.1016/j.eneco.2016.02.008

Pesaran, M. H., Shin, Y. and Smith, R. J. (2001). Bounds testing approaches to the analysis of level relationship. Journal of Applied Econometrics, 16, 289-326. https://doi.org/10.1002/jae.616

Pesaran, M. H. (2006). Estimation and inference in large heterogeneous panels with a multifactor error structure. Econometrica, 74(4), 967-1012. https://doi.org/10.1111/j.1468-0262.2006.00692.x

Pesaran, M. H. and Yamagata, T. (2008). Testing slope homogeneity in large panels. Journal of Econometrics, 142(1), 50-93. http://dx.doi.org10.1016/j.jeconom.2007.05.010

Sadorsky, P. (2010). The impact of financial development on energy consumption in emerging economies. Energy Policy, 38, 2528-2535. https://doi.org/10.1016/j.enpol.2009.12.048

Sadorsky, P. (2011). Financial development and energy consumption in central and eastern European frontier economies. Energy Policy, 39(2), 999-1006. https://doi.org/10.1016/j.enpol.2010.11.034

Salman, D. M. and Atya, E.M. (2014). What is the role of financial development and energy consumption on economic growth? New evidence from North African countries. International Journal of Finance \& Banking Studies, 3(1), 137-149. Retrieved from https://www.ssbfnet.com/ojs/index.php/ijfbs 
Ekonomi, Politika \& Finans Araştırmaları Dergisi, 2021, 6(1): 1-15

Journal of Research in Economics, Politics \& Finance, 2021, 6(1): 1-15

Shahbaz, M. and Lean, H. H. (2012). Does financial development increase energy consumption? The role of industrialization and urbanization in Tunisia. Energy Policy, 40, 473-479. https://doi.org/10.1016/j.enpol.2011.10.050

Topcu, M. and Altay, B. (2017). New insight into the finance-energy nexus: disaggregated evidence from Turkish sectors. International Journal of Financial Studies, 5(1), 1-16. https://doi.org/10.3390/ijfs5010001

Topcu, M. and Payne, J. E. (2017). The financial development-energy consumption nexus revisited. Energy Sources, Part B: Economics, Planning, and Policy, 12(9), 822-830. https://doi.org/10.1080/15567249.2017.1300959

Westerlund, J. (2007). Testing for error correction in panel data. Oxford Bulletin of Economics and Statistics, 69(6), 709-747. https://doi.org/10.1111/j.1468-0084.2007.00477.x

$\mathrm{Xu}, \mathrm{S}$. J. (2012). The impact of financial development on energy consumption in China: Based on SYSGMM estimation. Advanced Materials Research, 524-527, 2977-2981. https://doi.org/10.4028/www.scientific.net/AMR.524-527.2977

Zeren, F. and Koç, M. (2014). The nexus between energy consumption and financial development with asymmetric causality test: new evidence from newly industrialized countries. International Journal of Energy Economics and Policy, 4(1), 83-91. Retrieved from https://www.econjournals.com/index.php/ijeep 